\title{
Squamous Cell Carcinoma of The Larynx in a Developing Community
}

\author{
Wilson IB Onuigbo* \\ Department of Pathology, Medical Foundation and Clinic, Nigeria
}

Submission: July 30, 2018; Published: January 02, 2019

*Corresponding author: Wilson IB Onuigbo, Department of Pathology, Medical Foundation and Clinic, 8 Nsukka Lane, Enugu 40001, Nigeria

Abstract

The larynx is a peculiarly sited organ whose squamous cell carcinomas have elicited attention in different parts of the world. Therefore, what obtains in a developing community is deemed to be worthy of documentation, the choice being the Ibo ethnic group in Nigeria.

Keywords: Larynx; Squamous cell carcinoma; Epidemiology; Worldwide; Developing community

\section{Introduction}

A search of the literature on laryngeal squamous cell carcinoma was made personally. In alphabetical order, interesting data appeared in China [1] France [2] Germany [3] India [4] Israel [5] Romania [6] Taiwan [7] Tunisia [8] Turkey [9] and USA [10]. Therefore, comparable data are obtained from the Ibo ethnic group [11]. which is domiciled in a developing community in South Eastern Nigeria.

\section{Investigation}

Itwas hypothesized in Birmingham (UK) that the establishment of a histopathology data pool facilitates epidemiological analysis [12]. Therefore, as the pioneer pathologist in such a pool founded at Enugu, erstwhile capital city of the Eastern Region of Nigeria, I was opportuned to examine biopsies taken from Ibo patients, especially as I insisted on formalin-fixation and accompaniment of interesting data. Moreover, since I kept a personal copy of all the results, the analyses were fruitful. Let the tabular form be used here with regard to cases of squamous cell carcinoma of the larynx.

\section{Results}

\section{Discussion}

What stands out above is the preponderance of old patients (Table 1), the youngest being only in the 3rd decade. Let me appeal

Table 1: Epidemiological Data on Squamous Cell Carcinoma of The Larynx.

\begin{tabular}{|c|c|c|c|c|c|c|}
\hline No & Initials & Age & Sex & Doctor & Provisional diagnosis & Measurements \\
\hline 1 & EM & 50 & F & Obiakor & Tumor type? & Fragments \\
\hline 2 & NO & 40 & M & Anyaegbuna & Cancer & cm \\
\hline 3 & MF & 25 & F & Okafor & Carcinoma & Fragments \\
\hline 4 & UW & 65 & M & Ezeanolue & Cancer & Fragments \\
\hline 5 & OU & 65 & M & Anyaegbuna & Cancer & \\
\hline
\end{tabular}

to the traffic in the reprint request (RR), seeing that an Editor in 1986 reported that I am "the only active researcher" that he had "traced in the RR area" [13]. In this context, the account from the famous Anderson Hospital and Tumor Institute, Houston, USA, was specific regarding squamous cell carcinoma of the larynx thus [14]: "This disease usually occurs in men between the ages of 50 to 70." Indeed, most of the local patients were typical not only age-wise but also sex-wise. Little wonder that, from another giant Institution, namely, the Mayo Clinic and Mayo Foundation, Rochester, Minnesota [15]. a wide consultation was published concerning a 60-year-old man "with a squamous cell carcinoma of the larynx." Now, back to Internet sources, the Chinese paper emphasized "partial laryngectomy for the treatment of squamous cell carcinoma of the larynx" [1]. Therefore, it is of interest that one of the local patients underwent it successfully. Odd presentations are noteworthy. The German case arose "in multfocal pharyngolaryngeal oncocitic papillary cystadenoma" [3]. As for the Indian [4] the spindle cell carcinoma was "a more aggressive variant of the commonly occurring squamous cell carcinoma." The basaloid type appeared in Romania [6] and Turkey [9]. The association with chronic lymphoid leukemia manifested in Tunisia [8] while USA came up with the papillary form which "has emerged as a distinct entity from the more common keratinizing squamous cell carcinoma" [10]. 


\section{Global Journal of Otolaryngology}

\begin{tabular}{|c|c|c|c|c|c|c|}
\hline 6 & OE & 70 & M & Anyaegbuna & Cancer & Fragments \\
\hline 7 & OM & 60 & M & Okafor & Cancer & Fragments \\
\hline 8 & OV & 70 & M & Udekwu & Squamous cancer & Laryngectomy \\
\hline
\end{tabular}

\section{References}

1. Li S (2000) Long-term results of total versus partial laryngectomy for the treatment of squamous cell carcinoma of the larynx. Zhonghua Zhong Liu Za Zhi 22(5): 426-428.

2. Weber RS, Forasitere A, Rosenthal DI, Laccourreye O (2004) Controversies in the management of advanced laryngeal squamous cell carcinoma. Cancer 101(2): 211-219.

3. Stenner M, Müller KM, Koopmann M, Rudack C (2014) Squamous cell carcinoma of the larynx arising in multifocal pharyngolarygeal oncocytic papillary cystadenoma: A case report and review of the literature. Medicine 93(12): e70.

4. Baruah B, Sarawgi M, Dubey KP, Gupta A (2016) Spindle cell carcinoma of the larynx: A rare case report. Clin Cancer Investig J 5(1): 73-75.

5. Nachalon Y, Cohen O, Alkan U, Shvero J, Popovtzer A (2017) Characteristics and outcome of laryngeal squamous cell carcinoma in young adults. Oncol Lett 13(3): 1393-1397.

6. Oana C, Mariana A, Gentiana ML, Gabriela Izabela Baltat, Antonela Anca Nicolauescu, et al. (2015) Basaloid squamous cell carcinoma of the larynx: Case report. ARS Med Tomitana 1(21): 27-31.

7. Yang CH, Chang TC (2007) Squamous cell carcinoma of the larynx or hypopharynx clinically manifestating as thyroid tumor: A case report. J Intern Med Taiwan 18: 51-55.
8. Hammamia B, Mnejjaa M, Achoura I, Chakrouna A, Khabirb A, et al (2010) Association of squamous cell carcinoma of the larynx and chronic lymphoid leukemia. Euro Ann Otorhinolaryngol, Head Neck Dis 127(4): 153-155.

9. Tutar H, Aydil U, Ekinci O, Bakkal FK, Tutar VB, et al. (2014) The basaloid variant of squamous cell carcinoma of the larynx. Braz J Otorhinolaryngol 80(3): 245-250.

10. Dutta R, Husain Q Kam D, Dubal PM, Baredes S, et al. (2015) Laryngeal papillary squamous cell carcinoma: A population-based analysis of incidence and survival. Otolaryngol Head Neck Surg 153(1): 54-59.

11. Basden GT (1966) Niger Ibos Lond: Cass.

12. Macartney JC, Rollaston TP, Codling BW (1980) Use of a histopathology data pool for epidemiological analysis. J Clin Pathol 33(4): 351-353.

13. Swales J (1986) ESP in the big world of reprint requests. Eng Specific Purposes 5(1): 81-85.

14. Newman RK, Byers RM (1982) Squamous carcinoma of the larynx in patients under the age of 35 years. Otolaryngol Head Neck Surg 90(4): 431-433.

15. Bryce D, Pearson B (1986) Squamous cell carcinoma of the larynx. Head Neck Surg 122-126.

\section{Your next submission with Juniper Publishers will reach you the below assets}

- Quality Editorial service

- Swift Peer Review

- Reprints availability

- E-prints Service

- Manuscript Podcast for convenient understanding

- Global attainment for your research

- Manuscript accessibility in different formats

(Pdf, E-pub, Full Text, Audio)

- Unceasing customer service

Track the below URL for one-step submission https://juniperpublishers.com/online-submission.php 